\title{
Data and Methods: A Conceptual Approach to Intercultural Dialogue
}

\begin{abstract}
In this chapter, we discuss the constructivist perspective on concepts and explain how we utilize this in our analysis of concepts used by the Council of Europe and the European Union in their education policy documents. In this perspective, political language and administrative documents not only describe the reality of administrated issues but also participate in their construction and meaning-making. The authors emphasize the performativity of language and discuss its significance for political rhetoric. Besides the theoretical and methodological frameworks, we describe the data and elaborate on the genre of education policy documents. We also provide an overview of the development, contents, and goals of European education policies in general and discuss their challenges as 'soft law' instruments based on non-enforceable recommendations and incentives.
\end{abstract}

Keywords Constructivist perspective $\bullet$ Concept analysis $\bullet$ The Council of Europe $\bullet$ The European Union $\bullet$ Genre $\bullet$ Education policy documents

Politics emerge from competing discourses on the uses of power. As outcomes of politics, policies concretize political will through written statements of intent. Therefore, the use of language is a crucial element of policies. Intercultural dialogue has been both a political innovation and a 
conceptual change in diversity policies. Due to the discursive nature of politics, political innovations are commonly simultaneously conceptual innovations and conceptual changes regarding social and societal issues that embody politics (Farr 1989, 31). Political language in policy documents does not only describe the reality of policies but also participate in their production. In such documents, language produces problems as well as subjects, objects, and their-often hierarchical—relations (Shore et al. 2011). Moreover, political language not only shapes the issues being discussed, but it also modifies the ideas of the community being governed through policies (Lähdesmäki et al. 2019). Following Austin's (1982) speech act theory, political language has thus been perceived as a performative speech act-even though its explicit claims might not be fulfilled (see e.g. Skinner 2002).

Our work is firmly rooted in the previous social-constructivist research on European politics. For two decades, scholars have examined the European Union and its politics and policies by emphasizing discourses, rhetoric, narration, and the use of language as a space for both conscious and unconscious production of meaning (e.g. Rosamond 2000; Christiansen et al. 2001; Risse 2004; Light and Young 2009). Diez (2001, 88) has even argued that the history of the European Union, with its agreements, declarations, directives, and decisions, can be seen as a broad collection of speech acts.

The methodological framework of this book stems from a constructivist perspective on concepts, emphasizing their contested, ambiguous, controversial, and transforming nature (see Skinner 1989; Koselleck 2002; Guzzini 2005), and a constructionist approach to language use and linguistic meaning-making processes. Concepts are not only abstract theoretical categories that are used to describe and make sense of the object of speech. As Wiesner $(2019,9)$ notes, the meaning of concepts "has a decisive function in ordering the world around us". In political discourses, they are also indicators of social, institutional, and political changes, debates, and conflicts, since conceptual controversies are often simultaneously political controversies (Wiesner and Schmidt-Gleim 2014; Wiesner et al. 2017, 2018; Wiesner 2019; Lähdesmäki et al. 2019). Moreover, semantic transformations of concepts not only reflect changes in the object of speech; concepts are tools for making these changes (Ball et al. 1989). Thus, the constructivist perspective on concepts emphasizes their performative nature: concepts bring about action (Austin 1982; Guzzini 2005).

Our approach emphasizes the performativity of language and its broader significance for policy documents and political rhetoric. For us, policies 
function as 'actants' that create social and semantic spaces, webs of meanings, and action. Semantic transformations and new concepts renew political ideas and views, and function as tools for introducing and establishing new policies (Lähdesmäki et al. 2019). The concept of intercultural dialogue in the policy documents discursively generates the idea and ideals of encountering and governing diversity in Europe. Through acts of naming and categorizing issues, policy discourses modify the ways in which diverse political and societal problems are approached and defined (Shore and Wright 1997).

Although the Council of Europe and the European Union frequently refer to intercultural dialogue in their education policy documents, the concept is rarely more broadly explored and explained in them. However, the uses of the concept in these documents entail various implicit meanings discursively constructed by embedding in the policy language various other concepts, terms, and textual contexts. These can be used to combine differing elements as an assemblage (Newman and Clarke 2009, 26). Our analysis of these assemblages stems from Skinner's 'contextualism' in the research of concepts (on this in relation to Koselleck's conceptual history, see e.g. Palonen 2014).

We adopt Skinner's emphasis on the relations between language and power in the research of concepts. Skinner $(1999,60-61)$ argues that such research should

focus on the various terms - the entire normative vocabulary-in which such concepts are habitually expressed. These terms, the paradigms of which are perhaps the names of the virtues and vices, are those which perform evaluative as well as descriptive functions in natural languages.

In his take, concepts are seen less as statements about the world than as tools and weapons of ideological debate. Thus the aim is to understand what can be done with concepts in argumentation and how they function as the engine of social change (Skinner 1999, 62-63, 2002, 4, 177). Skinner $(2002,5)$ notes:

[W]e employ our language not merely to communicate information but at the same time to claim authority for our utterances, to arouse the emotions of our interlocutors, to create boundaries of inclusion and exclusion and to engage in many other exercises of social control.

This kind of language use characterizes the discussions on intercultural dialogue in the European education policy documents. 


\section{The Council of Europe and the European Union as Policymakers}

The Council of Europe and the European Union share an explicit interest in promoting culture, identity, and values described and defined as European in their policy discourses. Both also act in the field of education in various ways. Due to their different institutional natures, however, the premises of their action differ. The Council of Europe mainly works through conventions developed by its member states. These member states maintain their sovereignty but commit themselves to conventions that function as common legal standards to be followed at the national level. The member states of the Union, in contrast, transfer part of their national legislative and executive power to Union administrative bodies. Although its directives deal with education in a rather generic manner, the European Union has a broad impact on educational issues in its member states through a diverse array of decisions and recommendations on specific educational matters, as well as through various funding instruments and programmes regarding children and young people.

In terms of membership and geographical scope, the Council of Europe and the European Union represent two different ideas of Europe. While after Brexit the Union would include 27 member states that are bound together through diverse administrative bonds and forms of integration, the Council has 47 member states whose societal, economic, political, cultural, and religious contexts differ greatly. Geographically, the Council represents a much broader idea of Europe, spreading further to the east than the European Union and including transcontinental states (Lähdesmäki 2019).

Neither of these organizations should be seen as a single actor or a policymaker working unanimously towards a common goal. Their policy documents are created in cooperation with diverse actors-including policymakers from different sectors, external experts, and stakeholders consulted at various events during multistage policymaking processes (Lähdesmäki 2019). Their policy documents, thus, are a reflection or result of negotiations drawn together by secretaries, officers, or other implementors at these organizations. Moreover, the policy discourses and conceptual choices made by the Council of Europe and the European Union reflect those of other international organizations, such as UNESCO. Their discourses are also closely connected through common policy areas, goals, actors, and joint initiatives. The Council of Europe has 
had a major influence on the development and conceptualization of the European Union's policy discourse. The Council's rhetorical formulations and interest areas have often been absorbed into the Union's policy discourse and goals with only a short delay, particularly in questions related to culture (Sassatelli 2009, 43; Patel 2013, 6).

Even though the Council of Europe and the European Union share a common interest in impacting on education policies in Europe, their ability to do so is limited. In the European Union, education is dealt with according to the principle of subsidiarity: the competencies for education are recognized to lie with member states at the national, regional, and local level (e.g. EC 2017, 2). The education policies of both bodies can be considered as 'soft law' instruments based mostly on non-enforceable recommendations and incentives (see Dewey 2010). Their education policies thus have a highly 'symbolic nature' characterized by a limited legal framework, yet including ambitious objectives of social cohesion, inclusion, and identity-building. The symbolic nature of these policies is also highlighted by the abstract and affective rhetoric used in the policy documents.

\section{Policy Development for Intercultural Dialogue}

As described in the introductory chapter, both the Council of Europe and the European Union have been active in promoting intercultural dialogue as an approach in their diversity policies. The political and scholarly debates over multiculturalism speeded up the shift away from it to intercultural dialogue as a core focus of their diversity policy vocabulary. Next, we will briefly explore how the concept was adapted to their policy discourses.

The dialogical approach to intercultural encounter was initiated in the 1980s by UNESCO (Wiesand et al. 2008). A similar approach started to characterize Council of Europe and European Union initiatives and programmes during the 1990s. Even though some Council policy documents explicitly referred to intercultural dialogue in the 1990s (e.g. the Framework Convention for the Protection of National Minorities, 1995), the emergence of the concept in Council and Union policy discourses can be timed to the beginning of the 2000s. At that time, the Council of Europe started a process that resulted in its White Paper on Intercultural Dialogue, finally published in 2008.

This process was initiated by Bennett $(2001,65-66)$ in his report advising the Council of Europe to facilitate the development of international codes of best practice in cultural diversity by involving various stakehold- 
ers in the development of cultural diversity policies and supporting the establishment and coordination of research networks on them. The recommendations of the report were applied by consulting the diverse bodies of the Council and various organizations and communities in its member states, through a questionnaire study of practices and needs for diversity policies. On the basis of the survey, the Council of Europe published a White Paper on Intercultural Dialogue (2008) seeking to provide practical suggestions for responding to the various challenges that diversified European societies were considered to face through dialogue between cultures (see Bunjes 2013 for the development process of the White Paper). The concept had been used previously in some Council declarations, such as the Declaration on Intercultural Dialogue and Conflict Prevention (2003) and the Faro Declaration on the Council of Europe's Strategy for Developing Intercultural Dialogue (2005).

The concept emerged in the European Union's policy discourse in the same period. Intercultural dialogue had a central place in the Union's cultural agenda titled A European Agenda for Culture in a Globalising World, published in 2007. The following year, the Union celebrated the European Year of Intercultural Dialogue; one of its goals was to raise awareness of the concept. The core motive behind the European Commission's decision to celebrate this year was the eastern enlargement of the Union and anticipated need for its old and new citizens to know each other's cultures better. Other thematic foci of the year included diversification through immigration and impacts of globalization (Wiesand et al. 2008). The evaluation report found that the core goals of the year were not fully implemented. Since intercultural dialogue was not precisely defined, the concept risked being understood too narrowly, excluding discussion of the most challenging social and political issues regarding diversity (ECOTEC $2009,24)$.

Since then, the European Union has embedded intercultural dialogue into its policy objectives and operational guidelines in the areas of culture, citizenship, multilingualism, education, training, and sport - either explicitly or indirectly by referring to the need of developing intercultural skills and competences and creating dialogue between people in multicultural environments (Wiesand et al. 2008, 100; DIALLS 2018). The ERICart report (Wiesand et al. 2008, 100) noted, however, that "the context within which [the concept] is embedded, varies significantly across the different policies and in some cases there are indications that clear definitions have not been established". In the 2010 s, intercultural dialogue has 
been a priority area in the European Union's broad cultural programmes, Culture Programme 2007-2013, followed by Creative Europe 2014-2020.

More recently, the European Union has also emphasized intercultural dialogue in its policies regarding refugees and migrants. In response to the 'refugee crisis' in 2015, the Union sought to connect its cultural politics and diversity policies more closely to include refugees and migrants in European societies. Experts and stakeholders from cultural sector were involved in these attempts, resulting in two reports: Promoting Intercultural Dialogue and Bringing Communities Together through Culture in Shared Public Spaces (2016) and How Culture and the Arts Can Promote Intercultural Dialogue in the Context of the Migratory and Refugee Crisis (2017). In them, intercultural dialogue is the core concept used to deal with differences in diversified societies. In 2017, the Council of the European Union adopted conclusions on Culture in the European Union's External Relations by welcoming the European Commission's joint communication, Towards an EU Strategy for International Cultural Relations (2016). This communication lays the foundation for the Union's current and forthcoming cultural diplomacy policy by identifying three key work streams, of which the second focuses on "promoting culture and intercultural dialogue for peaceful inter-community relations" (EC 2016, 7). Over a decade, the concept has been adapted to the European Union's policy discourses in both its internal and external affairs.

Similarly, the Council of Europe has utilized the concept of intercultural dialogue in its diverse policy areas, emphasizing language learning, education, media, conflict prevention and management, post-conflict reconciliation, support for young refugees, asylum seekers, and displaced persons, and the promotion of global solidarity and cooperation. The Council of Europe's work on intercultural dialogue has resulted in various practical guidelines to advance its core goals. For example, the Council published a Toolkit for Conducting Intercultural Dialogue in 2012 as an outcome of its INGO Conference. Moreover, intercultural dialogue has been key to various programmes of the Directorate General of Democracy that have focused on democracy education among young people. The Council of Europe's work on advancing democratic societies and democratic culture, and on perceiving intercultural dialogue as a prerequisite for their processes and institutions, has concretized in its project that was realized in four phases between 2014 and 2017. As its result, the Council has created a conceptual model of the competences seen as important for citizens "to participate effectively in a culture of democracy" (CofE 2016, 3). The 20 
competences fall into four categories: values, attitudes, skills, and knowledge and critical understanding. As continuation of its work on promoting a culture of democracy, in 2018 the Council of Europe published the Reference Framework of Competences for Democratic Culture. The Framework seeks to meet a need which the Council saw in its member states for a clear focus and common goals in citizenship education (CofE $2018,5)$.

How do the Council of Europe and the European Union themselves define the concept of intercultural dialogue? In the Council White Paper (2008, 10-11),

[i]ntercultural dialogue is understood as an open and respectful exchange of views between individuals, groups with different ethnic, cultural, religious and linguistic backgrounds and heritage on the basis of mutual understanding and respect [-]. It operates at all levels-within societies, between the societies of Europe and between Europe and the wider world.

Besides the societal-level measures, the White Paper emphasizes the responsibility of grassroots actors in implementing intercultural dialogue. Beyond the school system, trade unions, workplaces, religious communities, and the public sphere, the White Paper extends its guidance to profoundly private spheres of human life, such as leisure activities and family environments (Lähdesmäki and Wagener 2015). Moreover, the White Paper (CofE 2008, 17) defines intercultural dialogue as

a process that comprises an open and respectful exchange of views between individuals and groups with different ethnic, cultural, religious and linguistic backgrounds and heritage, on the basis of mutual understanding and respect. It requires the freedom and ability to express oneself, as well as the willingness and capacity to listen to the views of others. Intercultural dialogue contributes to political, social, cultural and economic integration and the cohesion of culturally diverse societies. It fosters equality, human dignity and a sense of common purpose. It aims to develop a deeper understanding of diverse world views and practices, to increase co-operation and participation (or the freedom to make choices), to allow personal growth and transformation, and to promote tolerance and respect for the other.

The White Paper introduces intercultural dialogue as a new approach to diversity policy by differentiating it from multiculturalism. The European Union's definition of intercultural dialogue uses the same dis- 
course that stems from the critique of multiculturalism. The European Commission website (2019) notes:

Intercultural dialogue is, essentially, the exchange of views and opinions between different cultures. Unlike multiculturalism, where the focus is on the preservation of separate cultures, intercultural dialogue seeks to establish linkages and common ground between different cultures, communities, and people, promoting understanding and interaction.

The European Union's Decision on the European Year of Intercultural Dialogue (EC 2006, 44) emphasizes the contribution of different cultures to heritage and ways of life in the Union and describes the goals of intercultural dialogue as "learning to live together in harmony":

At the heart of the European project, it is important to provide the means for intercultural dialogue and dialogue between citizens to strengthen respect for cultural diversity and deal with the complex reality in our societies and the coexistence of different cultural identities and beliefs. Furthermore, it is important to highlight the contribution of different cultures to the Member States' heritage and way of life and to recognise that culture and intercultural dialogue are essential for learning to live together in harmony.

The Council of Europe's most recent definition of intercultural dialogue is formulated in the Reference Framework of Competences for Democratic Culture (2018):

Intercultural dialogue is an open exchange of views, on the basis of mutual understanding and respect, between individuals or groups who perceive themselves as having different cultural affiliations from each other. It requires the freedom and ability to express oneself, as well as the willingness and capacity to listen to the views of others. (CofE 2018, 74-75)

This document also recognizes various potential challenges in intercultural dialogue. As its glossary states:

Intercultural dialogue can be a difficult process. This is particularly the case when the participants perceive each other as representatives of cultures that have an adversarial relationship with one another (e.g. as a consequence of past or present armed conflict) or when a participant believes that their own 
cultural group has experienced significant harm (e.g. blatant discrimination, material exploitation or genocide) at the hands of another group to which they perceive their interlocutor as belonging. Under such circumstances, intercultural dialogue can be extremely difficult, requiring a high level of intercultural competence and very considerable emotional and social sensitivity, commitment, perseverance and courage. (CofE 2018, 75)

Both organizations base their notion of intercultural dialogue on particular 'shared European values' that are seen as the common legal, moral, and ethical framework for its implementation. These values-or rather a group of societal ideals and political principles of liberal democratic societies-are founded in human rights, democracy, and the rule of law. Moreover, the European Union commonly continues this list of values with respect for human dignity, freedom, equality, and the rights of persons belonging to minorities by defining them as common values to "a society in which pluralism, non-discrimination, tolerance, justice, solidarity and equality between women and men prevail", as the Treaty of Lisbon declares (EC 2008, Article 2).

Despite their good aims, European-level measures for advancing intercultural dialogue have been criticized for not reaching the national, regional, or local level. The ERICart report stated as early as 2008 that the European Union's agendas had not been uniformly incorporated in the national legislation or policies of member states (Wiesand et al. 2008, iv). Hadjisoteriou et al.'s $(2015,222)$ research also showed that the Union's turn towards intercultural education has influenced education policies, curricula, school textbooks, and teacher training in member states, though the European discourses often ran counter to national policy discourses. Moreover, the terminology of the intercultural dimension has been interpreted in diverse ways within national education policies (Hadjisoteriou et al. 2015, 233).

The idea and practice of intercultural dialogue has been broadly adopted by various other international actors such as the United Nations, UNESCO, OECD, European Cultural Foundation, the European Forum for the Arts and Heritage, and other NGOs and civil society platforms (Wiesand et al. 2008; Besley and Peters 2012). UNESCO's interest in 'interculturality' has been a particular inspiration for policies on intercultural dialogue in the Council of Europe and the European Union. In 2005, the UNESCO General Assembly adopted the Convention on the Diversity of Cultural Expressions that came into force in 2007. Its objec- 
tives include "to encourage dialogue among cultures with a view to ensuring wider and balanced cultural exchanges in the world in favour of intercultural respect and a culture of peace; and to foster interculturality in order to develop cultural interaction in the spirit of building bridges among peoples" (UNESCO 2007, 5). The convention does not utilize the concept of intercultural dialogue as such but approaches it through other terms such as the interaction of cultures.

\section{Data Selection and Characteristics}

The Council of Europe and European Union policy documents include a broad range of texts of varying form, length, and focus. Many of them simultaneously address issues relevant to different policy sectors, such as culture, education, sport, economics, employment, regional politics, social politics, migration, refugees, and minorities. Our research focuses on education policies. In order to recognize these in such a wide range of documents, we chose to follow how these organizations themselves identify their core education policies.

The European Union documents were selected from the EUR-Lex database - the official database of all its legal texts. In it, the Summaries of EU Legislation section includes a policy collection titled 'Education, training, youth, sport'. From within that, the sub-collection on 'Education and training' was selected as the data source. Our data concerning the European Union consists of all 48 documents in this collection, excluding the 'archived documents', that is, (versions of the) documents that are no longer in force. The Council of Europe documents were selected from its official website. The core education policy documents produced by the Council can be accessed from the education section of this website via the links 'resources' and 'official texts'. These 19 documents include 4 conventions, 3 charters, and 12 recommendations. The data was collected in summer 2018 and totals 67 documents.

The European Union documents in the data seek to tackle a variety of educational issues, such as e-learning, digital competences, youth work, entrepreneurship in education, vocational education, lifelong learning, promoting school success, children with migrant backgrounds, multilingualism, media literacy, transnational partnerships in education, teacher education, and gender equality. The overarching context of all these documents is naturally education and training, but their other common contexts relate to employment, economic growth, the labour market, mobility, 
creativity, innovation, competitiveness, diversity, equity, equal access, and social cohesion. Some of the documents focus on the diversification of society due to immigration and globalization, whereas others emphasize sustainable development related to societal and economic issues, as well as the challenges of climate change. The context of violent upheavals, such as terrorism, is also mentioned in some documents - and connected with the simultaneous aims of safeguarding European values and promoting the acceptance of diversity. The time frame of the European Union's documents in the data ranges from 1975 to 2018.

The Council of Europe documents in the data likewise addressed various topics, such as history teaching, children and adolescents of migrant backgrounds, promotion of plurilingualism, democratic citizenship, higher education, and common values. Besides education and training, the contexts of these documents include respect for cultural diversity, integration of migrants, enhancing democracy and human rights, and advancing fair societies. The time frame of the recommendations in the data ranges from 2000 to 2014, while that of the conventions and charters range from 1954 to 2015 . In addition, the data includes a compilation document of thematic extracts from several conventions, recommendations, resolutions, and reports, published in 2018.

The Council of Europe documents were produced by its various committees, including representatives from the state parties, and its recommendations created by different committees of ministers. Most Union documents were created by the European Commission or the Council of the European Union with other Union institutions or administrative bodies, such as the European Parliament and representatives of the governments of member states. The explicit audience of the documents issued by the European Union is usually other Union institutions, and in the case of the Council of Europe, its member states. Based on the issues addressed, the intended end users of the documents are diverse, including policymakers, national, regional, and local education authorities, teachers and educators, schools, institutes of vocational and higher education, civil associations and (I)NGOs, health and social workers, employers and trade unions, cultural institutions, researchers, and learners.

The documents seldom explicitly refer to their creators as 'we'. However, the position of 'we' as Europeans or as representatives of the Council of Europe or the European Union is often implicitly created in their texts by using expressions such as "our common European principles" (CofEU \& RofGofMS 2006, 2) and statements such as "each of the many national, regional, minority and migrant languages spoken in Europe adds a facet to 
our common cultural background" (CofEC 2008, 5) or "cultural diversity in our societies should be welcomed" (CofEU 2009, 7). In the Union documents, Europe and Europeans become associated with this "our"Europeans have a society and can, thus, welcome or not welcome diversity (that is "others", such as immigrants). In the Council of Europe documents, the 'we' position is more implicit. Since the documents always speak from the perspective of the Council (with reference to "common heritage", "shared ideals and principles", and a wish to promote European identity and include "others", such as immigrants, in European economic and cultural spheres), it is clear that the speaker position is a European one.

A policy document is a genre that seeks to influence people by appealing to the policy's relevance, timeliness, and importance. The aim of such documents is to improve conditions and practices that policymakers perceive as inadequate, deficient, malfunctioning, or problematic (Lähdesmäki et al. 2015) and to create a better future by applying language that is forward-looking and relies upon a belief in progress and innovation (Kowalczyk 2011). This kind of language characterizes the documents in our data. Moreover, coherent narratives are commonly constructed in the policy documents by showing that the issues have been addressed earlier. Therefore, the genre of the European policy documents is characterized by numerous references to their earlier policy documents, using phrases and expressions from them. The documents seek to present their policy positions as 'natural' consequences of earlier discourses in a logical continuum (Lähdesmäki et al. 2019).

\section{Concept Analysis in Practice}

The concept analysis of the data was guided by theoretical views on the performativity of language, constructivist perspectives on concepts, and contextualism. The focus was on how the concept of intercultural dialogue was both explicitly and implicitly dealt with and given meanings in the policy documents. In practice, our scrutiny was based on a qualitative analysis of explicit and implicit meanings, relations, and co-occurrences of concepts, terms, and themes used to discuss intercultural dialogue and closely related issues arising in the data.

First, we explored how the concept of intercultural dialogue was generally understood and dealt with in the documents and how its meanings were produced in relation to other concepts and terms, such as culture, cultural heritage, identity, inclusion, empathy, tolerance, multiculturalism, citizenship, participation, and social responsibility. In the analysis, we paid 
special attention to the values and ideals conveyed by these concepts and by the education policy documents in general. Appearances of explicit and implicit value statements were traced from the documents to deduce how (the argumentation for) the need of intercultural dialogue was constructed and how it was related to the general aims, values, and ideals of the Council of Europe and the European Union. Second, we engaged in an in-depth analysis of the (CO-)occurrences and thematic overlapping of concepts that were closely related to intercultural dialogue. In this phase, we also explored the relationship between concepts (e.g. inclusion and integration, tolerance and mutual respect), and traced the links between the concepts of intercultural dialogue and intercultural skills and competences. This illuminated the conceptual network and semantics of the concept of intercultural dialogue.

We then extended our analysis to include broader 'densities' of interrelated concepts in selected policy documents. We scrutinized instances where many of the core concepts related to intercultural dialogue appeared at the same time. Our analysis of these densities revealed the closely intertwined nature of certain concepts and terms in the data and indicated how the understandings of intercultural dialogue depend not only on explicit definitions but equally on how interrelated concepts and terms are used in textual contexts of the documents. Moreover, we explored these densities in relation to the subject matter of the policy documents.

Concepts carry affective associations and cultural connotations. In the final stage of our conceptual analysis, we examined the affective nature of concepts and the affective rhetoric used in the data. Drawing on theories of affect (discussed more in detail in the fifth chapter), our research elaborated on the 'poetic dimension' of European education policy discourse (see Lähdesmäki 2017). Our analysis of conceptual densities showed that many of the conceptual conglomerations form affective peaks or rhetorical pinnacles that transmit the idea of intercultural dialogue-and the values attached to it-more forcefully than the mere definitions of the concept are able to do. Therefore, we concluded by focusing on the affective impact of these dense co-occurrences of the core concepts related to intercultural dialogue. We argue that when concepts with affective value (see e.g. Ahmed 2004; Lähdesmäki 2017) are brought together, their dense co-occurrences become heavy with affect. These dense co-occurrences are contrasted in the policy documents with the distancing impact of common policy jargon and sections with 'sparse' co-occurrences of concepts. Consequently, our analysis traced the affective transmission (Brennan 2004) or mediation of European ideals and values in the chosen docu- 
ments by relating the findings to existing research on affects within policy discourse. By examining what kind of affects and affective connotations "stick" (see Ahmed 2004) to the concept of intercultural dialogue, we suggest that the Council of Europe and the European Union use affective rhetoric in their education policy documents to promote their idea of intercultural dialogue and to legitimize their policies to advance it. Affective rhetoric can, thus, be perceived as a central tool in the governing of diversities in European education policies.

\section{REFERENCES}

Ahmed, S. 2004. The Cultural Politics of Emotion. Edinburgh: Edinburgh University Press.

Austin, J.L. 1982. How to Do Things with Words: The Williams James Lectures Delivered at Harvard University in 1955. New York: Oxford University Press.

Ball, T., J. Farr, and R.L. Hanson. 1989. Editors' Introduction. In Political Innovation and Conceptual Change, ed. T. Ball, J. Farr, and R.L. Hanson, 1-5. Cambridge: Cambridge University Press.

Bennett, T. 2001. Part I: Differing Diversities: Transversal Study on the Theme of Cultural Policy and Cultural Diversity. In Differing Diversities: Transversal Study on the Theme of Cultural Policy and Cultural Diversity, ed. T. Bennett, 7-69. Strasbourg: Council of Europe Publishing.

Besley, T., and M.A. Peters. 2012. Interculturalism, Education and Dialogue. Bern: Peter Lang.

Brennan, T. 2004. The Transmission of Affect. Ithaca: Cornell University Press.

Bunjes, U. 2013. The Intercultural Milestone: The History of the Council of Europe's White Paper on Intercultural Dialogue. In Interculturalism and Multiculturalism: Similarities and Differences, ed. M. Barrett, 43-52. Paris: Council of Europe.

Christiansen, T., K.E. Jørgensen, and A. Wiener, eds. 2001. The Social Construction of Europe. London: Sage Publications.

CofE (Council of Europe). 2008. White Paper on Intercultural Dialogue: "Living Together As Equals in Dignity”. Strasbourg: Council of Europe.

- 2016. Competences for Democratic Culture. Living Together as Equals in Culturally Diverse Democratic Societies. Strasbourg: Council of Europe.

- 2018. Reference Framework of Competences for Democratic Culture. Volume 1: Context, Concepts and Model. Strasbourg: Council of Europe.

CofEC (the Commission of the European Communities). 2008. Communication from the Commission to the European Parliament, the Council, the European Economic and Social Committee and the Committee of the Regions Multilingualism: an asset for Europe and a shared commitment. COM(2008) 566 final. Brussels: Commission of the European Communities. 
CofEU \& RofGofMS (Council of the European Union \& the Representatives of the Governments of the Member States). 2006. Resolution of the Council and of the Representatives of the Governments of the Member States, Meeting Within the Council, on the Recognition of the Value of Non-formal and Informal Learning within the European Youth Field. (2006/C 168/01). Official Journal of the European Union C168: 1-3.

CofEU (Council of the European Union). 2009. Council Conclusions of 26 November 2009 on the Education of Children with a Migrant Background. (2009/C 301/07). Official Journal of the European Union C301: 5-8.

Dewey, P. 2010. Power in European Union Cultural Policy. In International Cultural Policies and Power, ed. J.P. Singh, 113-126. New York: Palgrave Macmillan.

DIALLS. 2018. Cultural Analysis Framework. https://dialls2020.eu/wp-content/uploads/2019/09/resubmitted-cultural-analysis-framework-with-coversheet-pdf.

Diez, T. 2001. Speaking 'Europe': The Politics of Integration Discourse. In The Social Construction of Europe, ed. T. Christiansen, K.E. Jørgensen, and A. Wiener, 85-100. London: Sage.

EC (European Commission). 2006. Decision no 1983/2006/EC of the European Parliament and of the Council of 18 December 2006 concerning the European Year of Intercultural Dialogue (2008). Official Journal of the European Union L412: 44-50.

- 2008. Treaty of Lisbon. Brussels: European Commission.

. 2016. Joint Communication to the European Parliament and the Council: Towards an EU Strategy for International Cultural Relations. JOIN (2016) 29 Final, June 8. Brussels: European Commission.

- 2017. Communication from the Commission to the European Parliament, the Council, the European Economic and Social Committee and the Committee of the Regions Strengthening European Identity Through Education and Culture. The European Commission's Contribution to the Leaders' Meeting in Gothenburg, November 17. COM(2017) 673 Final. Brussels: European Commission.

- 2019. Culture: Intercultural Dialogue. Web Site. https://ec.europa.eu/ culture/policy/strategic-framework/intercultural-dialogue_en.

Ecotec. 2009. Evaluation of the European Year of Intercultural Dialogue 2008: Final Report. Birmingham, Ecotec.

Farr, J. 1989. Understanding Conceptual Change Politically. In Political Innovation and Conceptual Change, ed. T. Ball, J. Farr, and R.L. Hanson, 24-49. Cambridge: Cambridge University Press.

Guzzini, S. 2005. The Concept of Power: A Constructivist Analysis. Millennium: Journal of International Studies 33 (3): 495-521.

Hadjisoteriou, C., D. Faas, and P. Angelides. 2015. The Europeanisation of Intercultural Education? Responses from EU Policy-makers. Educational Review 67 (2): 218-235. 
Koselleck, R. 2002. The Practice of Conceptual History: Timing History, Spacing Concepts. Stanford: Stanford University Press.

Kowalczyk, J. 2011. The Immigration Problem' and European Education Reforms: From the Education of Migrants' Children to Intercultural Education. European Education 42 (4): 5-24.

Lähdesmäki, T. 2017. Politics of Affect in the EU Heritage Policy Discourse: An Analysis of Promotional Videos of Sites Awarded with the European Heritage Label. International Journal of Heritage Studies 23 (8): 709-722.

- 2019. Conflicts and Reconciliation in Postmillennial Heritage Policy Discourses of the Council of Europe and the European Union. In Dissonant Heritages and Memories in Contemporary Europe, ed. T. Lähdesmäki, L. Passerini, S. Kaasik-Krogerus, and I. van Huis, 25-50. New York: Palgrave Macmillan.

Lähdesmäki, T., and A. Wagener. 2015. Discourses on Governing Diversity in Europe: Critical Analysis of the White Paper on Intercultural Dialogue. International Journal of Intercultural Relations 44: 13-28.

Lähdesmäki, T., P.C.C.A. Heynderickx, A. Wagener, and S.M.F. Dieltjens. 2015. Negations and Negativity as Linguistic Devices in Policy Discourse of Intercultural Cities. Journal of Multicultural Discourses 10 (3): 332-348.

Lähdesmäki, T., S. Kaasik-Krogerus, and K. Mäkinen. 2019. Genealogy of the Concept of Heritage in the European Commission's Policy Discourse. Contributions to the History of Concepts 14 (1): 115-139.

Light, D., and C. Young. 2009. European Union Enlargement, Post-Accession Migration and Imaginative Geographies of the 'New Europe': Media Discourses in Romania and the United Kingdom. Journal of Cultural Geography 26 (3): 281-303.

Newman, J., and J. Clarke. 2009. Publics, Politics and Power: Remaking the Public in Public Services. London: Sage.

Palonen, K. 2014. Politics and Conceptual Histories. Rhetorical and Temporal Perspectives. Baden-Baden: Nomos/Bloomsbury.

Patel, K.K. 2013. Introduction. In The Cultural Politics of Europe. European Capitals of Culture and European Union Since the 1980s, ed. K.K. Patel, 1-15. London: Routledge.

Risse, T. 2004. European Institutions and Identity Change: What Have We Learned? In Transnational Identities. Becoming European in the EU, ed. R.K. Herrmann, T. Risse, and M.B. Brewer, 247-271. Oxford: Rowman and Battlefield.

Rosamond, B. 2000. Theories of European Integration. Basingstoke: Palgrave.

Sassatelli, M. 2009. Becoming Europeans. Cultural Identity and Cultural Policies. New York: Palgrave Macmillan.

Shore, C., and S. Wright. 1997. Policy: A New Field for Anthropology. In Anthropology of Policy: Critical Perspectives on Governance and Power, ed. C. Shore and S. Wright, 3-39. London: Routledge. 
Shore, C., S. Wright, and D. Però, eds. 2011. Policy Worlds. Anthropology and the Analysis of Contemporary Power. New York: Berghahn Books.

Skinner, Q. 1989. Language and Political Change. In Political Innovation and Conceptual Change, ed. T. Ball, J. Farr, and R.L. Hanson, 6-23. Cambridge: Cambridge University Press.

- 1999. Rhetoric and Conceptual Change. In Finnish Yearbook of Political Thought 3, ed. S. Haikala, J. Kotkavirta, and K. Palonen, 60-73. Jyväskylä: SoPhi.

- 2002. Visions of Politics-Volume 1: Regarding Method. Cambridge: Cambridge University Press.

UNESCO. 2007. Convention on the Diversity of Cultural Expressions. Paris: UNESCO.

Wiesand, A., I. Heiskanen, R. Mitchell, D. Cliché, M. Fisher, and L. Marsio. 2008. Sharing Diversity: National Approaches to Intercultural Dialogue in Europe. Bonn: European Institute for Comparative Cultural Research.

Wiesner, C. 2019. Inventing the EU as a Democratic Polity. New York: Palgrave Macmillan.

Wiesner, C., and M. Schmidt-Gleim. 2014. The Meanings of Europe: Introduction. In The Meanings of Europe. Changes and Exchanges of a Contested Concept, ed. C. Wiesner and M. Schmidt-Gleim, 1-15. London: Routledge.

Wiesner, C., T. Haapala, and K. Palonen. 2017. Debates, Rhetoric, and Political Action. Basingstoke: Palgrave Macmillan.

Wiesner, C., A. Björk, H.-M. Kivistö, and K. Mäkinen. 2018. Introduction: Shaping Citizenship as a Political Concept. In Shaping Citizenship. A Political Concept in Theory, Debate and Practice, ed. C. Wiesner, A. Björk, H.-M. Kivistö, and K. Mäkinen, 1-16. London: Routledge.

Open Access This chapter is licensed under the terms of the Creative Commons Attribution 4.0 International License (http://creativecommons.org/licenses/ by $/ 4.0 /$ ), which permits use, sharing, adaptation, distribution and reproduction in any medium or format, as long as you give appropriate credit to the original author(s) and the source, provide a link to the Creative Commons licence and indicate if changes were made.

The images or other third party material in this chapter are included in the chapter's Creative Commons licence, unless indicated otherwise in a credit line to the material. If material is not included in the chapter's Creative Commons licence and your intended use is not permitted by statutory regulation or exceeds the permitted use, you will need to obtain permission directly from the copyright holder.

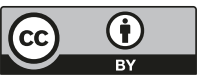

